\title{
Reflections on Death in Philosophical/Existential Context
}

\author{
Nikos Kokosalakis ${ }^{1}$
}

Published online: 27 July 2020

(C) Springer Science+Business Media, LLC, part of Springer Nature 2020

\begin{abstract}
Is death larger than life and does it annihilate life altogether? This is the basic question discussed in this essay, within a philosophical/existential context. The central argument is that the concept of death is problematic and, following Levinas, the author holds that death cannot lead to nothingness. This accords with the teaching of all religious traditions, which hold that there is life beyond death, and Plato's and Aristotle's theories about the immortality of the soul. In modernity, since the Enlightenment, God and religion have been placed in the margin or rejected in rational discourse. Consequently, the anthropocentric promethean view of man has been stressed and the reality of the limits placed on humans by death deemphasised or ignored. Yet, death remains at the centre of nature and human life, and its reality and threat become evident in the spread of a single virus. So, death always remains a mystery, relating to life and morality.
\end{abstract}

Keywords Life $\cdot$ Philosophical $\cdot$ Existential $\cdot$ Death $\cdot$ Soul $\cdot$ Transcendence $\cdot$ Modernity

What a piece of work is a man! how noble in reason! how infinite in faculty! In form and moving, how express and admirable! In action, how like an angel! in apprehension, how like a god! the beauty of the world! the paragon of animals! And yet, to me, what is this quintessence of dust?

William Shakespeare (1890: 132), Hamlet, Act 2, scene $2,303-312$.

In mid-2019, the death of Sophia Kokosalakis, my niece and Goddaughter, at the age of 46, came like a thunderbolt to strike the whole family. She was a world-famous fashion designer who combined, in a unique way, the beauty and superb aesthetics of ancient and classical Greek sculptures and paintings with fashion production of clothes and jewellery. She took the aesthetics and values of ancient and classical Greek civilization out of the museums to the contemporary art of fashion design. A few months earlier she was full of life, beautiful, active, sociable and altruistic, and highly creative. All that was swept away quickly by an aggressive murderous cancer. The funeral

Nikos Kokosalakis

nikoskokosalakis@hotmail.com

P.O. Box 49, 34002 Vasiliko, Evia, Greece $(\kappa \eta \delta \varepsilon i \alpha)$ - a magnificent ritual event in the church of Panaghia Eleftherotria in Politeia Athens - accorded with the highly significant moving symbolism of the rite of the Orthodox Church. Her parents, her husband with their 7-year-old daughter, the wider family, relatives and friends, and hundreds of people were present, as well as eminent representatives of the arts. The Greek Prime Minister and other dignitaries sent wreaths and messages of condolences, and flowers were sent from around the world. After the burial in the family grave in the cemetery of Chalandri, some gathered for a memorial meal. This was a high profile, emotional final goodbye to a beloved famous person for her last irreversible Journey.

Sophia's death was circumscribed by social and religious rituals that help to chart a path through the transition from life to death. Yet, the pain and sorrow for Sophia's family has been very deep. For her parents, especially, it has been indescribable, indeed, unbearable. The existential reality of death is something different. It raises philosophical questions about what death really means in a human existential context. How do humans cope with it? What light do religious explanations of death shed on the existential experience of death and what do philosophical traditions have to say on this matter?

In broad terms religions see human life as larger than death, so that life's substance meaning and values for each person are not exhausted with biological termination. Life goes on. For most religions and cultures there is some notion of immortality of the soul and there is highly significant ritual and symbolism for the 
dead, in all cultures, that relates to their memory and offers some notion of life beyond the grave. In Christianity, for example, life beyond death and the eternity and salvation of the soul constitutes the core of its teaching, immediately related to the incarnation, death, and resurrection of Christ. Theologically, Christ's death and resurrection, declare the defeat of death by the death and the resurrection of the son of God, who was, both, God and perfectly human (theanthropos). This teaching signifies the triumph of life over death, which also means, eschatologically, the salvation and liberation of humankind from evil and the injustice and imperfection of the world. It refers to another dimension beyond the human condition, a paradisiac state beyond the time/space configuration, a state of immortality, eternity and infinity; it points to the sublimation of nature itself. So, according to Christian faith, the death of a human being is a painful boundary of transition, and there is hope that human life is not perishable at death. There is a paradox here that through death one enters real life in union with God. But this is not knowledge. It is faith and must be understood theologically and eschatologically.

While the deeply faithful, may accept and understand death as passage to their union with God, Sophia's death shows that, for ordinary people, the fear of death and the desperation caused by the permanent absence of a beloved person is hard to bear - even with the help of strong religious faith. For those with lukewarm religious faith or no faith at all, religious discourse and ritual seems irrelevant or even annoying and irrational. However, nobody escapes the reality of death. It is at the heart of nature and the human condition and it is deeply ingrained in the consciousness of adult human beings. Indeed, of all animals it is only humans who know that they will die and according to Heidegger (1967:274) "death is something distinctively impending". The fear of death, consciously or subconsciously, is instilled in humans early in life and, as the ancients said, when death is near no one wants to die.

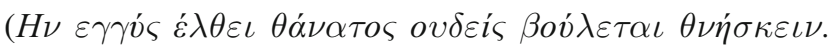
[Aesopus Fables]). In Christianity even Christ, the son of God, prayed to his father to remove the bitter cup of death before his crucifixion (Math. 26, 38-39; Luke, 22, 41-42).

The natural sciences say nothing much about the existential content and conditions of human death beyond the biological laws of human existence and human evolution. According to these laws, all forms of life have a beginning a duration and an end. In any case, from a philosophical point of view, it is considered a category mistake, i.e. epistemologically and methodologically wrong, to apply purely naturalistic categories and quantitative experimental methods for the study, explanation and interpretation of human social phenomena, especially cultural phenomena such as the meaning of human death and religion at large. As no enlightenment on such issues emerges from the natural sciences, maybe insights can be teased out from philosophical anthropological thinking.

Philosophical anthropology is concerned with questions of human nature and life and death in deeper intellectual, philosophical, dramaturgical context. Religion and the sacred are inevitably involved in such discourse. For example, the verses from Shakespeare's Hamlet about the nature of man, at the preamble of this essay, put the matter in a nutshell. What is this being who acts like an angel, apprehends and creates like a god, and yet, it is limited as the quintessence of dust? It is within this discourse that I seek to draw insights concerning human death. I will argue that, although in formal logical/scientific terms, we do not know and cannot know anything about life after/beyond death, there is, and always has been, a legitimate philosophical discourse about being and the dialectic of life/death. We cannot prove or disprove the existence and content of life beyond death in scientific or logical terms any more than we can prove or disprove the existence of God scientifically. ${ }^{1}$

Such discourse inevitably takes place within the framework of transcendence, and transcendence is present within life and beyond death. Indeed, transcendence is at the core of human consciousness as humans are the only beings (species) who have culture that transcends their biological organism. ${ }^{2}$ According to Martin (1980:4) "the main issue is... man's ability to transcend and transform his situation". So human death can be described and understood as a cultural fact immediately related to transcendence, and as a limit to human transcendental ability and potential. But it is important, from an epistemological methodological point of view, not to preconceive this fact in reductionist positivistic or closed ideological terms. It is essential that the discourse about death takes place within an open dialectic, not excluding transcendence and God a priori, stressing the value of life, and understanding the limits of the human potential.

\section{The Problem of Meaning in Human Death}

Biologically and medically the meaning and reality of human death, as that of all animals, is clear: the cessation of all the functions and faculties of the organs of the body, especially the heart and the brain. This entails, of course, the cessation of consciousness. Yet, this definition tells us nothing about why only the human species, latecomers in the universe, have always worshiped their gods, buried their dead with elaborate

\footnotetext{
${ }^{1}$ David Martin (1980:16) puts the matter about human and divine autonomy as follows: "Indeed, it is all too easy to phrase the problem so that the autonomy of God and the autonomy of man are rival claimants for what science leaves over". This concurs with his, (1978:12), understanding of religion, (which I share), as "acceptance of a level of reality beyond the observable world known to science, to which we ascribe meanings and purposes completing and transcending those of the purely human realm".

${ }^{2}$ We do not know how and when human beings acquired this capacity during the evolutionary process of the species. It characterises however a radical shift from nature to culture as the latter is defined by Clifford Geertz (1973:68): "an ordered system of meanings and symbols .... in terms of which individuals define their world, express their feelings and make their judgements".
} 
ritual, and held various beliefs about immortality. Harari (2017:428-439) claims that, in the not too distant future, sapiens could aim at, and is likely to achieve, immortality and the status of Homo Deus through biotechnology, information science, artificial intelligence and what he calls the data religion. I shall leave aside what I consider farfetched utopian fictional futurology and reflect a little on the problem of meaning of human death and immortality philosophically.

We are not dealing here with the complex question of biological life. This is the purview of the science of biology and biotechnology within the laws of nature. Rather, we are within the framework of human existence, consciousness and transcendence and the question of being and time in a philosophical sense. According to Heidegger (1967:290) "Death, in the widest sense, is a phenomenon of life. Life must be understood as a kind of Being to which there belongs a Being-in-the-world". He also argues (bid: 291) that: "The existential interpretation of death takes precedence over any biology and ontology of life. But it is also the foundation for any investigation of death which is biographical or historiological, ethnological or psychological". So, the focus is sharply on the issue of life/death in the specifically human existential context of being/life/death. Human life is an (the) ultimate value, (people everywhere raise their glass to life and good health), and in the midst of it there is death as an ultimate threatening eliminating force. But is death larger than life, and can death eliminate life altogether? That's the question. Whereas all beings from plants to animals, including man, are born live and die, in the case of human persons this cycle carries with it deep and wide meaning embodied within specific empirical, historical, cultural phenomena. In this context death, like birth and marriage, is a carrier of specific cultural significance and deeper meaning. It has always been accompanied by what anthropologists refer to as rites of passage, (Van Gennep, 1960 [1909]; Turner, 1967; Garces-Foley, 2006). These refer to transition events from one state of life to another. All such acts and rites, and religion generally, should be understood analysed and interpreted within the framework of symbolic language. (Kokosalakis, 2001, 2020). In this sense the meaning of death is open and we get a glimpse of it through symbols.

Death, thus, is an existential tragic/dramatic phenomenon, which has preoccupied philosophy and the arts from the beginning and has been always treated as problematic. According to Heidegger (1967: 295), the human being Dasein (being-there) has not explicit or even theoretical knowledge of death, hence the anxiety in the face of it. Also, Dasein has its death, "not in isolation, but as codetermined by its primordial kind of Being" (ibid: 291). He further argues that in the context of being/time/ death, death is understood as being-towards-death (Sein zum Tode). Levinas ${ }^{3}$ (2000:8), although indebted to Heidegger, disagrees radically with him on this point because it posits being-

\footnotetext{
${ }^{3}$ For a comprehensive extensive and impressive account and discussion of Levinas' philosophy and work, and relevant bibliography, see Bergo (2019).
}

towards death (Sein zum Tode) "as equivalent to being in regard to nothingness". Leaving aside that, phenomenologically the concept of nothingness itself is problematic (Sartre: 3-67), Levinas (2000:8) asks: "is that which opens with death nothingness or the unknown? Can being at the point of death be reduced to the ontological dilemma of being or nothingness? That is the question that is posed here." In other words, Levinas considers this issue problematic and wants to keep the question of being/ life/death open. Logically and philosophically the concept of nothingness is absolute, definitive and closed whereas the concept of the unknown is open and problematic. In any case both concepts are ultimately based on belief, but nothingness implies knowledge which we cannot have in the context of death.

Levinas (ibid: 8-9) argues that any knowledge we have of death comes to us "second hand" and that "It is in relation with the other that we think of death in its negativity" (emphasis mine). Indeed, the ultimate objective of hate is the death of the other, the annihilation of the hated person. Also death "[is] a departure: it is a decease [deces]". It is a permanent separation of them from us which is felt and experienced foremost and deeply for the departure of the beloved. This is because death is "A departure towards the unknown, a departure without return, a departure with no forward address". Thus, the emotion and the sorrow associated with it and the pain and sadness caused to those remaining. Deep-down, existentially and philosophically, death is a mystery. It involves "an ambiguity that perhaps indicates another dimension of meaning than that in which death is thought within the alternative to be/not- to- be. The ambiguity: an enigma" (ibid: 14). Although, as Heidegger (1967:298-311) argues, death is the only absolute certainty we have and it is the origin of certitude itself, I agree with Levinas (ibid: 10-27) that this certitude cannot be forthcoming from the experience of our own death alone, which is impossible anyway. Death entails the cessation of the consciousness of the subject and without consciousness there is no experience. We experience the process of our dying but not our own death itself. So, our experience of death is primarily that of the death of others. It is our observation of the cessation of the movement, of the life of the other.

Furthermore, Levinas (Ibid: 10-13) argues that "it is not certain that death has the meaning of annihilation" because if death is understood as annihilation in time, "Here, we are looking for other dimension of meaning, both for the meaning of time ${ }^{4}$ and for the meaning of death". ${ }^{5}$ So death is a phenomenon with dimensions of meaning beyond the historical space/time

\footnotetext{
${ }^{4}$ Perhaps it is worth mentioning here that the meaning of the concept of time, as it was in Cartesian Philosophy and Newtonian physics, has changed radically with Einstein's theories of relativity and contemporary quantum physics (Heisenberg 1959). Heisenberg's uncertainty principle (Hilgervood and Uffink, 2016) is very relevant to non- deterministic conceptions of time/ space and scientific and philosophical discourse generally.

${ }^{5}$ Various religions articulate the structure of these meanings in different cultural contexts symbolically and all of them involve the divine and an eschatological metaphysical dimension beyond history, beyond our experience of time and space.
} 
configuration. Levinas dealt with such dimensions extensively not only in his God, Death and Time (2000) but also in his: Totality and Infinity (1969); Otherwise than Being, or Beyond Essence (1991); and, Of God Who comes to mind (1998). So, existentially/phenomenologically such dimensions inevitably involve the concept of transcendence, the divine, and some kind of faith. Indeed, the question of human death has always involved the question of the soul. Humans have been generally understood to be composite beings of body/soul or spirit and the latter has also been associated with transcendence and the divine. In general the body has been understood and experienced as perishable with death, whereas the soul/spirit has been understood (believed) to be indestructible. Thus beyond or surviving after/ beyond death. Certainly this has been the assumption and general belief of major religions and cultures, ${ }^{6}$ and philosophy itself, until modernity and up to the eighteenth century.

Ancient and classical Greek philosophy preoccupied itself with the question of the soul. ${ }^{7}$ Homer, both in the Iliad and the Odyssey, has several reference on the soul in hades (the underworld) and Pythagoras of Samos (580-496 b.c.) dealt with immortality and metempsychosis (reincarnation). ${ }^{8}$ In all the tragedies by Sophocles (496-406 b,c,), Aeschylus (523-456 b. c.), and Euripides ( $480-406$ b.c.), death is a central theme but it was Plato 9 (428?-347 b.c.) and Aristotle ${ }^{10}$ (384-322 b.c.) - widely acknowledged as the greatest philosophers of all times - who wrote specific treatises on the soul. Let us look at their positions very briefly.

\section{Plato on the Soul}

Plato was deeply concerned with the nature of the soul and the problem of immortality because such questions were foundational to his theory of the forms (ideas), his understanding of ethics, and his philosophy at large. So, apart from the dialogue Phaedo, in which the soul and its immortality is the central subject, he also referred to it extensively in the Republic, the Symposium and the Apology as well in the dialogues: Timaeus, Gorgias, Phaedrus, Crito, Euthyfron and Laches.

\footnotetext{
${ }^{6}$ Ancient Egyptian culture is well known for its preoccupation with life after death, the immortality of the soul and the elaborate ritual involved in the mummification of the Pharaohs. See: anen.wikipedia.org/wiki/Ancient Egyptian_funerary_practices). Also the findings of archaeological excavations of tombs of kings in all ancient cultures constitute invaluable sources of knowledge not only about the meaning of death and the beliefs and rituals associated with it in these cultures but also of life and religion and politics and society at large.

${ }^{7}$ For an extensive account of general theories of the soul in Greek antiquity see: Lorenz (2009).

${ }^{8}$ For a good account on Pythagoras' views on the transmigration of the souls see: Huffman (2018).

9 For a recent good account on the diachronic importance of Plato's philosophy see: Kraut (2017).

${ }^{10}$ For a very extensive analytical account and discussion of Aristotle's philosophy and work with recent bibliography see: Shields (2016).
}

The dialogue Phaedo ${ }^{11}$ is a discussion on the soul and immortality between Socrates (470-399 b.c.) and his interlocutors Cebes and Simias. They were Pythagorians from Thebes, who went to see Socrates in prison just before he was about to be given the hemlock (the liquid poison: means by which the death penalty was carried out at the time in Athens). Phaedo, his disciple, who was also present, is the narrator. The visitors found Socrates very serene and in pleasant mood and wondered how he did not seem to be afraid of death just before his execution. Upon this Socrates replies that it would be unreasonable to be afraid of death since he was about to join company with the Gods (of which he was certain) and, perhaps, with good and beloved departed persons. In any case, he argued, the true philosopher cannot be afraid of death as his whole life, indeed, is a practice and a preparation for it. So for this, and other philosophical reasons, death for Socrates is not to be feared. (Phaedo; 64a-68b).

Socrates defines death as the separation of the soul from the body (64c), which he describes as prison of the former while joined in life. The body, which is material and prone to earthly materialistic pleasures, is an obstacle for the soul to pursue and acquire true knowledge, virtue, moderation and higher spiritual achievements generally $(64 d-66 e)$. So, for the true philosopher, whose raison-d'être is to pursue knowledge truth and virtue, the liberation of the soul from bodily things, and death itself when it comes, is welcome because life, for him, was a training for death anyway. For these reasons, Socrates says is "glad to go to hades" (the underworld) (68b).

Following various questions of Cebes and Simias about the soul, and its surviving death, Socrates proceeds to provide some logical philosophical arguments for its immortality. The main ones only can be mentioned here. In the so called cyclical argument, Socrates holds that the immortality of the soul follows logically from the relation of opposites (binaries) and comparatives: Big, small; good, bad; just, unjust; beautiful, ugly; good, better; bad; worse, etc. As these imply each other so life/death/life are mutually inter-connected, (70e71d). The second main argument is that of recollection. Socrates holds that learning, in general, is recollection of things and ideas by the soul which always existed and the soul itself pre-existed before it took the human shape. (73a-77a). Socrates also advises Cebes and Simias to look into themselves, into their own psyche and their own consciousness in order to understand what makes them alive and makes them speak and move, and that is proof for the immortality of the soul (78ab). These arguments are disputed and are considered inadequate and anachronistic by many philosophers today (Steadman, 2015; Shagulta and Hammad, 2018; and others) but the importance of Phaedo lies in the theory of ideas and values and the concept of ethics imbedded in it.

\footnotetext{
${ }^{11}$ For an overview of Phaedo in English with commentary and the original Greek text see: Steadman (2015).
} 
Plato's theory of forms (ideas) is the basis of philosophical idealism to the present day and also poses the question of the human autonomy and free will. Phaedo attracts the attention of modern and contemporary philosophers from Kant (17241804) and Hegel (1770-1831) onwards, because it poses the existential problems of life, death, the soul, consciousness, movement and causality as well as morality, which have preoccupied philosophy and the human sciences diachronically. In this dialogue a central issue is the philosophy of ethics and values at large as related to the problem of death. Aristotle, who was critical of Plato's idealism, also uses the concept of forms and poses the question of the soul as a substantive first principle of life and movement although he does not deal with death and immortality as Plato does.

\section{Aristotle on the Soul}

Aristotle's conception of the soul is close to contemporary biology and psychology because his whole philosophy is near to modern science. Unlike many scholars, however, who tend to be reductionist, limiting the soul to naturalistic/positivistic explanations, (as Isherwood, 2016, for instance, does, unlike Charlier, 2018, who finds relevance in religious and metaphysical connections), Aristotle's treatment of it, as an essential irreducible principle of life, leaves room for its metaphysical substance and character. So his treatise on the soul, (known now to scholars as De Anima, Shields, 2016), is closely related to both his physics and his metaphysics.

Aristotle sees all living beings (plants, animals, humans) as composite and indivisible of body, soul or form (Charlton, 1980). The body is material and the soul is immaterial but none can be expressed, comprehended or perceived apart from matter $\left(v^{\prime} \lambda \eta\right)$. Shields (2016) has described this understanding and use of the concepts of matter and form in Aristotle's philosophy as hylomorphism [hyle and morphe, (matter and form)]. The soul

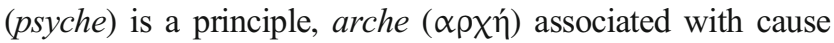
$(\alpha \iota \tau i \alpha)$ and motion (kinesis) but it is inseparable from matter. In plants its basic function and characteristic is nutrition. In animals, in addition to nutrition it has the function and characteristic of sensing. In humans apart from nutrition and sensing, which they share with all animals, in addition it has the unique faculty of noesis and logos. (De Anima ch. 2). Following this, Heidegger (1967:47) sees humans as: 'Dasein, man's Being is 'defined' as

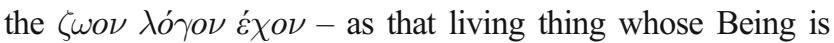
essentially determined by the potentiality for discourse". (So, only human beings talk, other beings do not and cannot).

In Chapter Five, Aristotle concentrates on this unique property of the human soul, the logos or nous, known in English as mind. The nous (mind) is both: passive and active. The former, the passive mind, although necessary for noesis and knowledge, is perishable and mortal ( $\varphi \theta \alpha \rho \tau$ ćs). The latter, the poetic mind is higher, it is a principle of causality and creativity, it is energy, aitia. So this, the poetic the creative mind is higher. It is the most important property of the soul and it is immaterial, immortal and eternal. Here Aristotle considers the poetic mind as separate from organic life, as substance entering the human body from outside, as it were. Noetic mind is the divine property in humans and expresses itself in their pursuit to imitate the prime mover, God that is.

So, Aristotle arrives here at the problem of immortality of the soul by another root than Plato but, unlike him, he does not elaborate on the metaphysics of this question beyond the properties of the poetic mind and he focuses on life in the world. King (2001:214) argues that Aristotle is not so much concerned to establish the immortality of the human individual as that of the human species as an eidos. Here, however, I would like to stress that we should not confuse Aristotle's understanding with contemporary biological theories about the dominance and survival of the human species. But whatever the case may be, both Aristotle's and Plato's treatises on the soul continue to be inspiring sources of debate by philosophers and others on these issues to the present day.

\section{Death in Modernity ${ }^{12}$}

It is banal to say that life beyond death does not preoccupy people in modernity as it did before and that, perhaps, now most people do not believe in the immortality of the soul. In what Charles Taylor (2007) has extensively described as A SECULAR AGE he frames the question of change in religious beliefs in the west as follows: "why was it virtually impossible not to believe in God in, say, 1500 in our western society, while in 2000 many of us find this not only easy, but even inescapable?" (p. 25). The answer to this question is loaded with controversy and is given variously by different scholars. ${ }^{13}$ Taylor (ibid: 65-75, 720-726) shows how and why beliefs have changed radically in modernity. Metaphysical transcendent beliefs on life and death have shrunk into this-worldly secular conceptions in what he calls, "the immanent frame". As a consequence, transcendence and the sacred were exiled from the world or reduced to "closed world structures". 14 In this context many scholars spoke of "the death of God" (ibid: 564-575).

\footnotetext{
$\overline{12}$ By modernity here is meant the general changes which occurred in western society and culture with the growth of science and technology and the economy, especially after the Enlightenment, and the French and the Industrial Revolutions, which have their cultural roots in the Renaissance, the Reformation and Protestantism.

${ }^{13}$ See, for instance, Wilson (1969) and Martin (1978) for radically different analyses and interpretations of secularization.

${ }^{14}$ Marxism is a good example. God, the sacred and tradition generally are rejected but the proletariat and the Party acquire a sacred significance. The notion of salvation is enclosed as potentiality within history in a closed system of the class struggle. This, however, has direct political consequences because, along with the sacred, democracy is exiled and turned into a totalitarian system. The same is true, of course, at the other end of the spectrum with fascism.
} 
In criticizing postmodern relativism, which brings various vague conceptions of God and transcendence back in play, Gellner (1992:80-83) praises what he calls Enlightenment Rationalist fundamentalism, which "at one fell swoop eliminates the sacred from the world". Although he acknowledges that Kant, the deepest thinker of the Enlightenment, left morality reason and knowledge outside the purview of the laws of nature, thus leaving the question of transcendence open, he still claims that Enlightenment rationalism is the only positive scientific way to study religious phenomena and death rituals. This position seems to be epistemologically flawed, because it pre-empts what concerns us here, namely, the assumptions of modernity for the nature of man and its implications for the meaning and reality of death.

In rejecting religion and traditional conceptions of death, Enlightenment rationalism put forward an overoptimistic, promethean view of man. What Vereker (1967) described as the "God of Reason" was the foundation of eighteenth century optimism. The idea was that enlightened rationalism, based on the benevolent orderly laws of nature, would bring about the redeemed society. Enlightened, rational leaders and the gradual disappearance of traditional religious beliefs, obscurantism and superstitions, which were sustained by the ancient regime, would eventually transform society and would abolish all human evil and social and political injustice. Science was supportive of this view because it showed that natural and social phenomena, traditionally attributed to divine agencies and metaphysical forces, have a clear natural causation. These ideas, developed by European philosophers (Voltaire 1694 1778; Rousseau, 1712-1778; Kant, 1724-1804; Hume, 1711-1776; and many others), were foundational to social and political reform, and the basis of the French Revolution (1789-1799). However, the underlying optimism of such philosophical ideas about the benevolence of nature appeared incompatible with natural phenomena such as the great earthquake in Lisbon in 1755, which flattened the city and killed over 100,000 people. Enlightenment rationalism overemphasised a promethean, anthropocentric view of man without God, and ignored the limits of man and the moral and existential significance of death.

In his critique of capitalism, in the nineteenth century, Marx (1818-1883), promoted further the promethean view of man by elevating him as the author of his destiny and banishing God and religion as "the opium of the people". In his Origin of the Species (1859), Charles Darwin also showed man's biological connections with primates, thereby challenging biblical texts about the specific divine origin of the human species. He confirmed human dominance in nature. Important figures in literature, however, such as Dostoevsky (1821-1881) and Tolstoy (1828-1910), pointed out and criticised the conceit and arrogance of an inflated humanism without God, promoted by the promethean man of modernity.
By the end of the twentieth century the triumph of science, biotechnology, information technology, and international capitalist monetary economics, all of them consequences of modernity, had turned the planet into a global village with improved living standards for the majority. Medical science also has doubled average life expectancy from what it was in nineteenth century and information technology has made, almost every adult, owner of a mobile smart phone. Moreover, visiting the moon has inflated man's sense of mastery over nature, and all these achievements, although embodying Taylor's (1992) malaise of modernity at the expense of the environment, have strengthen the promethean view and, somehow, ignored human limits. As a consequence, the reality of death was treated as a kind of taboo, tucked under the carpet.

This seems a paradox because, apart from the normal death of individuals, massive collective deaths, caused by nature and by hate and barbarity from man to man, were present in the twentieth century more than any other in history. The pandemic of Spanish flue 1917-1919 killed 39 million of the world's population according to estimates by Baro et al. (2020). In the First World War deaths, military and civilians combined, were estimated at 20.5 million (Wikipedia). In the Second World War an estimated total of 70-85 million people perished, (Wikipedia). This did not include estimates of more than seven million people who died in the gulags of Siberia and elsewhere under Stalin. But Auschwitz is indicative of the unlimited limits, which human barbarity and cruelty of man to man, can reach. Bauman (1989:x), an eminent sociologist, saw the Holocaust as a moral horror related to modernity and wrote: "The Holocaust was born and executed in modern rational society, at the high stage of our civilization and at the peak of human cultural achievement, and for this reason it is a problem of that society, civilization and culture."

Questions associated with the mass death are now magnified by the spread of the coronavirus (Covid-19). This has caused global panic and created unpredictability at all levels of society and culture. This sudden global threat of death makes it timely to re-examine our values, our beliefs (secular or religious), and the meaning of life. Max Weber (1948: 182), who died a hundred years ago in the pandemic of great influenza, was sceptical and pessimistic about modernity, and argued that it was leading to a cage with "specialists without spirit, sensualists without heart; this nullity imagines that it had attained a level of civilization never before achieved."

\section{Epilogue}

So, what does this examination of philosophical anthropology illuminate in terms of questions of human nature and life and death in deeper intellectual, philosophical, dramaturgical context? Now, we are well into the twenty-first century, and with 
the revolution in information science, the internet, biotechnology and data religion, the promethean view of man seems to have reached new heights. Yet, massive death, by a single virus this time, threatens again humanity; are there any lessons to be learned? Will this threat, apart from the negativity of death, bring back the wisdom, which T. S. Elliot said we have lost in modern times? Will it show us our limits? Will it reduce our conceit and arrogance? Will it make us more humble, moderate, prudent, and more humane for this and future generations, and for the sake of life in this planet at large? These are the questions arising now amongst many circles, and it is likely that old religious and philosophical ideas about virtuous life and the hope of immortality (eschatologically) may revive again as we are well within late modernity (I do not like the term postmodernity, which has been widely used in sociology since the 1980s).

The central argument of this essay has been that death has always been and remains at the centre of life. Philosophically and existentially the meaning of death is problematic, and the natural sciences cannot produce knowledge on this problem. Religious traditions always beheld the immortality of the soul and so argued great philosophers like Plato and Aristotle. Modernity, since the Enlightenment, rejected such views as anachronistic and advanced an anthropocentric promethean, view of man, at the expense of the sacred and transcendence at large. Instead, within what Taylor (1967: 537-193) has described as the immanent frame, it developed "closed world structures," which are at the expense of human nature and human freedom. One consequence of this has been massive death during the twentieth century.

Following Levinas (2000), I argued that death should not be understood to lead to nothingness because nothingness means certitude and positive knowledge, which we cannot have existentially in the case of death. In this sense the reality of death should not be understood to lead to annihilation of life and remains a mystery. Moreover, the presence and the reality of death as a limit and a boundary should serve as educative lesson for both the autonomy and creativity of man and against an overinflated promethean view of her/his nature.

\section{Further Reading}

Baro, R. Ursua, J, Weng, J. 2020. Coronovirus meets the great influenza pandemic. https://voxeu.otg/article/coronovirus-meets-greatinfluenza-pandemic.

Bauman, Z. 1989. Modernity and the Holocaust. Cambridge: Polity Press Bergo, Betina. 2019. Emmanuel Levinas. The Stanford Encyclopaedia of Philosophy. Fall 2019 edition, Edward Zalta (ed.) https://plato. stanford.edu/entries/levinas/.

Charlier, P. 2018. The notion of soul and its implications on medical biology. Ethics, medicine and public health June 2018, pp. 125 127. https://doi.org/10.1016/j.jemep.2018.05.005.
Charlton, W, 1980, Aristotle's definition of the soul. Phonesis, vol. 25, no. 2, pp. 170-186.

Garsey-Foley, K. 2006. Death and Religion in a Changing World. MC Sharpe.

Geertz, C. 1993. The Interpretation of Cultures. London: Hutchinson.

Gellner, E. 1992. Postmodernism Reason and Religion. London and New York: Routledge.

Harari, N. Y, 2017. Homo Deus: A Short History of Tomorrow. London: Vintage.

Heidegger, M. 1967. Being and Time. Oxford: Basil Blackwell.

Heisenberg, W. 1959. Physics and Philosophy. London: Allen and Unwin.

Hilgervoord, J, and Uffing, J. 2016. The Uncertainty Principle. Stanford Encyclopaedia of Philosophy (Winter 2018 edition) Edward Zalta (ed.) https://plato.stanford.edu/archives/win2016/entries/qtuncertainty

Huffman, C. 2018. Pythagoras. Stanford Encyclopedia of Philosophy (winter 2018 edition) Edward Zalta (ed.). https://plato.stanford. edu/entries/pythagoras/.

Isherwood, D. 2016. Science at last explains our soul: exploring the human condition with clues from science. https://www. zmescience.com/science/science-explains-our-soul/.

King, R. 2001. Aristotle on Life and Death. London: Duckworth.

Kokosalakis, N. 2001. Symbolism (religious)) and Icon. International Encyclopedia of Social and Behavioural Science. Amsterdam: Elsevier.

Kokosalakis, N. 2020. Symbolism and Power in David Martin's Sociology of Religion. Society. vol. 57, pp. 173-179. https://doi. org/10.1007/s12115-020-00462-x.

Kraut, R. 2017. Plato. The Stanford Encyclopaedia of Philosophy (Fall 2017 edition) Edward N. Zaltman (ed.) https://plato.stanford.edu/ archives/fall2017/entries/plato/.

Levinas, E. 1969. Totality and Infinity: An Essay on Exteriority. (Trans. A. Lingis). Pittsburgh: Duquesne University Press.

Levinas, E, 1991. Otherwise than Being or Beyond Essence. (trans. A. Lingis). Dordrecht: Kluwer Academic.

Levinas, E. 1998. Of God Who Comes to Mind. (trans, Betina Bergo). Stanford CA: Stanford University Press.

Levinas, E. 2000. God, Death and Time. (tr. Betina Bergo) Stanford Calif: Stanford University Press.

Lorenz, H. 2009. Ancient Theories of the Soul. The Stanford Encyclopaedia of Philosophy. (Summer 2009 edition), Edward N. Zalta (ed.) https://plato.stanford.edu/archives/sum2009/entries/ ancient-soul/. Accessed 22 Apr 2009.

Martin, D. 1978. A General Theory of Secularization. Oxford: Basil Blackwell.

Martin, D. 1980. The Breaking of the Image. Oxford: Basil Blackwell

Sartre, Jean-Paul. 1969. Being and Nothingness: An Essay on Phenomenological Ontology. London: Methuen.

Shagufta, B. and M. Hamad. 2018. Concept of immortality in Platos's Phaedo. Al-Hikmat, Vol. 36, pp. 1-12.

Shakespeare, W. 1890, Charles Knight (ed.) The Works of William Shakespeare. London: Routledge. Vol V, p. 132.

Shields, C. 2015. De Anima. (tr. with an introduction and commentary). Oxford: Oxford University Press.

Shields, C. 2016. Aristotle. The Stanford Encyclopaedia of Philosophy (winter 2016 edition) Edward N. Zalta (ed.). https://plato.stanford. edu/entries/aristotle/. Accessed 29 Jul 2015.

Steadman, G. 2015. Plato's Phaedo, 1 edition. https:// geoffreysteadman.files.wordpress.com.....PDF. Accessed 15 Jun 2015.

Taylor, C. 1992. The Malaise of Modernity. Cambridge MA: Harvard University Press.

Taylor, C. 2007. A Secular Age. Cambridge MA Harvard University Press.

Turner, V. 1969. The Ritual Process. London; Penguin. 
Van Gennep, A. 1960 [1909]. The Rites of Passage. (tr. From the French), Vereker, C. 1967. Eighteenth Century Optimism. Liverpool: Liverpool University Press.

Weber, Max, 1968. The Protestant Ethic and the Spirit of Capitalism. London: Unwin University Books (9nth Impression).

Wilson, B. 1969. Religion in Secular Society. London: Penguin Books.

Publisher's Note Springer Nature remains neutral with regard to jurisdictional claims in published maps and institutional affiliations.
Nikos Kokosalakis was a senior lecturer in sociology at the University of Liverpool until 1995, when he left as Honorary Senior Fellow, and then a research professor in social policy in KEKMOKOP, Panteion University in Athens until 2010. He now lives in 34002, Evia, Greece. He extends his gratitude to Professor Lynne Hunt, his friend from Perth, W. Australia, who read, commented, and edited a draft of this essay. 